\title{
Pelatihan Daring Aplikasi Media Sosial dalam Pemasaran Produk Kerajinan Bambu di Selaawi, Garut, Jawa Barat
}

\author{
Santi Susanti ${ }^{1}$, Rachmaniar ${ }^{2}$, Iwan Koswara ${ }^{2}$ \\ 1, 2 Universitas Padjadjaran, Indonesia
}

\begin{abstract}
A B S T R A C T
ONLINE TRAINING OF SOCIAL MEDIA APPLICATION FOR MARKETING BAMBOO CRAFT PRODUCT IN SELAAWI, GARUT, WEST JAVA. The distribution of goods and services needs marketing to reach the potential customers. The development of internet technology expand the marketing of goods and services from traditional to online market. The bamboo artisans of Selaawi Subdistrict, Garut Regency, realized that it was necessary to market their products online to increase the market share of their craft products, which are currently distributed offline. The Community Service (PPM) Team of Fikom Unpad conducted "Online Training on Social Media Applications for Marketing Bamboo Craft Products in Selaawi, Garut Regency" for creative bamboo economic people in Selaawi Subdistrict, who have not used social media or not optimally used social media as a marketing and promotion channels for bamboo handicraft products. This PPM aims to elevate bamboo artisan's knowledge in using social media to support the marketing and distribution of bamboo handicraft products directly to customers and sales agents. The social media skills is expected to invite buyers, and increase bamboo artisan's income. PPM activity presented speakers who owned Amygdala Bamboo, the Head of Selaawi subdistrict, the coordinator of bamboo craft artisans in Selaawi, and PPM Team of Fikom Unpad. This PPM activity was conducted online through Zoom Cloud Meetings, which was attended by bamboo crafts artisans and other participants.
\end{abstract}

\begin{tabular}{llll} 
Keywords: & \multicolumn{3}{c}{ Bamboo Crafts, Marketing, Online Training, Social Media. } \\
\hline Received: & Revised: & Accepted: & Available online: \\
23.04 .2020 & 09.07 .2020 & 22.10 .2020 & 30.11 .2020 \\
\hline
\end{tabular}

\section{Suggested citation:}

Susanti, S., Rachmaniar, \& Koswara, I. (2020). Pelatihan Daring Aplikasi Media Sosial dalam Pemasaran Produk Kerajinan Bambu di Selaawi, Garut, Jawa Barat. Jurnal Pengabdian Pada Masyarakat, 5(4), 943-953. https://doi.org/10.30653/002.202054.666

Open Access I URL: http://ppm.ejournal.id/index.php/pengabdian/article/view/666

\footnotetext{
${ }^{1}$ Corresponding Author: Program Studi Film dan Televisi, Fikom Universitas Padjadjaran; Jl. Raya BandungSumedang KM 21, Jatinangor, Sumedang, Jawa Barat, Indonesia. Email: santi.susanti@unpad.ac.id
} 


\section{PENDAHULUAN}

Kerajinan bambu merupakan salah satu komoditas kerajinan unggulan di Jawa Barat. Sedikitnya, 100 sentra kerajinan bambu tersebar di empat wilayah, yakni Garut, Tasikmalaya, Ciamis dan Cianjur (bisnisbandung.com, 2017). Beragam jenis kerajinan dihasilkan untuk keperluan rumah tangga, dekorasi, fashion, hobi, dan sebagainya. Misalnya tempat sampah, keranjang buah, kotak surat, pot bunga, tempat koran, pembatas dinding, kap lampu, tempat kue, alas piring dan sebagainya. Sentra terbesar kerajinan bambu di Jawa Barat berada di Kabupaten Tasikmalaya, yang memiliki tidak kurang dari 34 sentra dengan sedikitnya 1.567 unit usaha yang tersebar di Kecamatan Leuwisari, Salawu, dan Singaparna. Setiap tahun, produksi kerajinan bambu dari kabupaten ini mencapai 6,96 juta unit senilai Rp 26,94 miliar.

Kerajinan bambu di Selaawi merupakan usaha kecil dan menengah yang dikelola dengan skala rumah tangga (home industry). Para pengelolanya adalah pengrajin dan keluarganya. Meski dikelola secara sederhana, akan tetapi, industri yang berbasis kreatifitas ini mampu bertahan dalam kondisi yang sulits sekalipun. Bahkan dalam kondisi badai pandemi Covid-19 yang menerpa Indonesia sejak Maret 2020 lalu pun tidak lantas menjadikan industri kerajinan di Selaawi berhenti total. Meski sebagian distribusi atau penjualan langsung kerajinan bambu kepada pembeli terhenti, seperti yang dialami pengrajin sangkar burung di Desa Mekarsari, pengrajin lainnya yang menggeluti anyaman bambu masih bertahan dan menghasilkan produk untuk dikirim kepada pembeli yang memesan melalui media sosial atau telpon.

Distribusi produk kerajinan disebar ke pasar lokal, juga untuk memenuhi permintaan dari luar negeri, seperti Belanda dan Malaysia, meskipun dilakukan oleh sebagian pengusaha kerajinan bambu. Sebagian besar distribusi produk kerajinan, dilakukan secara konvensional, yaitu mengirimnya ke pedagang kerajinan bambu di Garut dan sekitarnya dan beberapa wilayah di Jawa Barat, seperti Bandung dan Cirebon.

Sementara itu, Harry Mawardi, creative entrepreneur industri bambu, mengatakan, kendala yang berlangsung di antara para pengrajin umumnya adalah komunikasi, termasuk di Kabupaten Garut. Harry, yang bekerjasama dengan pengrajin di Desa Mekarsari, mengatakan, umumnya, para pengrajin fokus pada usahanya masingmasing dan tidak ada ikatan organisasi sehingga persaingan di antara pengusaha produk kerajinan bambu cukup besar. Menurut Harry, persoalan pemasaran dan promosi dirasakan masih kurang, karena distribusinya masih konvensional (Mawardi, 2020).

Sementara itu, hasil kajian Dinas Perindustrian, Perdagangan dan Pengelolaan Pasar (Perindagpas) Kabupaten Garut, pada tahun 2015, menunjukkan hal serupa. Para pengrajin olahan bambu di Kabupaten Garut, termasuk di Selaawi, memiliki persoalan dalam pemasaran dan promosi kerajinan bambu yang mereka hasilkan (Disperindagpas Kabupaten Garut \& Buana, 2015).

Oleh karena itu, untuk meningkatkan pendapatan para pengrajin bambu di Selaawi, Kabupaten Garut, diperlakukan pengetahuan tambahan untuk meningkatkan keterampilan para pengrajin atau pengusaha kerajinan bambu dalam penggunaan media sosial sebagai saluran pemasaran dan promosi produk kerajinan bambu Selaawi. Upaya untuk membantu pengrajin dalam memanfaatkan media sosial 
adalah dengan memberikan pelatihan seputar media sosial, mulai dari pengenalan hingga pemanfaatannya. Dengan demikian, persoalan yang menjadi bahasan dalam kegiatan PPM ini adalah "Bagaimana mengoptimalkan pemanfaatan media sosial dalam memasarkan produk kerajinan bambu di Kecamatan Selaawi, Kabupaten Garut?

Teknologi yang digunakan dalam pelatihan ini adalah teknologi mobile berbasis internet yang digunakan dalam ponsel cerdas atau smartphone. Smartphone memuungkinkan pengrajin atau pengusahan kerajinan bambu dapat mengakses media sosial dengan mudah, dari mana saja, kapan saja sehingga pemasaran dan promosi produk dapat dilangsungkan secara fleksibel.

Berkembangnya penggunaan media sosial yang semula sebagai media komunikasi menjadi media pemasaran produk yang dihasilkan maupun dijualkan oleh warga net, menjadi peluang yang sangat terbuka untuk mengembangkan pemasaran. Potensi pasar digital di Indonesia sangat besar. Berdasarkan jumlah pengakses, Indonesia menempati urutan kedua terbanyak pengakses Facebook dengan jumlah 35,4 juta user, melebihi jumlah penduduk Kanada, serta urutan keempat terbesar pengakses Twitter dengan jumlah 4,8 juta user, setara dengan jumlah penduduk Singapura.

Berdasarkan cara warga Indonesia mengakses internet, $83 \%$ dari internet cafe, $22 \%$ dari smartphone, dan 16\% dari rumah. Dengan demikian, potensi pangsa pasar online sangat terbuka luas dan memiliki beragam keuntungan, antara lain, pemasaran online terus tumbuh, pasar selalu terbuka dan bisa diakses kapan saja dan dimana saja. Menjadi wirausahawan online pun dapat dilakukan kapan pun.

Banyak media sosial yang dapat digunakan untuk pemasaran dan promosi produk atau jasa, termasuk kerajinan bambu yang dihasilkan pengrajin di Selaawi, Kabupaten Garut. Media sosial yang seirng digunakan untuk pemasaran dan promosi di antarnya Facebook, Instagram dan Twitter.

Selama ini, pemasaran kerajinan bambu di Selaawi lebih banyak menggunakan cara konvensional dengan mendistribusikannya ke pusat-pusat kerajinan di sekitar Garut, maupun ke Bandung dan Bogor. Kegiatan PPM ini diselenggarakan untuk menambah wawasan para pengrajin mengenai manfaat media sosial dalam memasarkan produk kerajinan bambu yang mereka hasilkan agar dapat meraih pasar yang lebih luas. Raihan pasar lebih luas, diharapkan dapat menambah pendapatan para pengrajin yang biasanya diperoleh melalui pemasaran secara konvensional

Di Indonesia, terdapat 48 jenis bambu yang potensial, tetapi yang diproses untuk kegunaan komersial baru 9 jenis (Kasmudjo, 2010). Bambu merupakan material yang unik karena kekuatannya yang luar biasa, memiliki sifat regeneratif dan nilai keindahan yang alami. Bambu dikenal sebagai material yang ramah lingkungan dan sumber daya alam yang dapat diperbarui.

Produk yang dapat dihasilkan dari pengolahan bambu mencapai lebih dari 60 macam. Produk tersebut dapat menggunakan bambu bulat, bambu belahan dan iratan. Kabupaten Garut dikenal sebagai wilayah dengan andalan utama produk pertanian. Namun, dalam pelaksanaannya, tidak sedikit masyarakat yang memanfaatkan lingkungannya sebagai pendukung aktivitas ekonominya secara turun temurun pada wilayah tertentu seperti pembuatan produk kerajinan berbahan dasar bambu, yang salah satunya dilakukan oleh masyarakat Kecamatan Selaawi. 
Kecamatan Selaawi dikenal sebagai penghasil produk kerajinan bambu yang dijual atau digunakan secara langsung untuk memenuhi kebutuhan sendiri dan memenuhi kebutuhan luar daerah sekitarnya, antara lain Bandung, Purwakarta, Cirebon, Karawang, Tasikmalaya, Tangerang, dan lainnya.

Nilai tambah produk merupakan keunggulan yang dimiliki produk berdasarkan fungsi dan kegunaan produk tersebut apabila dibandingkan dengan produk lainnya (produk substitusi). Berdasarkan kajian Disperindagpas pada tahun 2015, produk kerajinan bambu yang dihasilkan secara tradisional banyak yang tergantikan oleh produk substitusi karena memiliki fungsi lebih dan lebih tahan lama masa pakainya dibandingan produk kerajinan bambu.

Keberadaan pasar untuk setiap produk merupakan bagian utama dalam meningkatkan nilai tambah dari suatu produk. Kondisi pasar produk kerajinan bambu secara umum masih lebih banyak konsumen lokal atau daerah sekitarnya sehingga sulit menembus pasar di luar wilayah daerahnya. Hasil produk kerajinan pun hanya mampu memenuhi kebutuhan lokal, karena kapasitas produksi yang masih terbatas seiring dengan keterbatasan jumlah pengrajin serta teknologi yang digunakan yang sebagian besar menggunakan tangan (Disperindagpas Kabupaten Garut \& Buana, 2015).

Media sosial adalah sebuah media online. Kehadirannya yang berbasis internet menunjukkan telah terjadi pergeseran arah penggunaan media komunikasi, yang semula bersifat klasik (media elektronik dan cetak) menjadi media baru (new media) berbasis internet yang menjadi saluran akses dalam berbagai bidang, yaitu pendidikan, budaya, sosial, ekonomi, hukum, juga politik.

Andreas Kaplan dan Michael Haenlein mendefinisikan media sosial sebagai "Suatu kelompok aplikasi berbasis internet yang membangun di atas dasar ideologi dan teknologi Web 2.0, dan yang memungkinkan penciptaan dan pertukaran user-generated content" (Kaplan \& Haenlein, 2010). Media sosial dikenal juga sebagai situs jejaring sosial, yang mengizinkan user untuk dapat terhubung dengan cara membuat informasi pribadi sehingga dapat terhubung dengan orang lain. Informasi pribadi itu bisa berupa foto atau tulisan.

Media sosial memudahkan para penggunanya berpartisipasi, berbagi dan menciptakan isi informasi dalam blog, jejaring sosial, woki, forum dan dunia virtual lainnya. Blog, jejaring sosial dan wiki mungkin merupakan bentuk media sosial yang paling umum digunakan oleh masyarakat di seluruh dunia (Ardianto, 2011: 165)

Dalam media sosial, setiap orang bisa membuat web page pribadi, kemudian terhubung dengan teman-teman untuk berbagi informasi dan berkomunikasi. Jika media konvensional menggunakan media cetak dan media broadcast, maka media sosial menggunakan internet. Saat teknologi internet dan mobile phone makin maju, maka media sosial pun ikut tumbuh pesat. Kini, untuk mengakses Facebook atau Twitter misalnya, bisa dilakukan di mana saja dan kapan saja hanya dengan melalui telepon selular. Demikian cepatnya orang dapat mengakses media sosial, mengakibatkan terjadinya fenomena besar terhadap arus informasi, tidak hanya di negara-negara maju, juga di negara berkembang seperti di Indonesia.

Media sosial atau social networking (jejaring sosial) yang umum diketahui dan digunakan antara lain Blog, Facebook, Twitter, Instagram, WhatsApp, Youtube, Google Plus, Path dan sebagainya. Jika media tradisional menggunakan media cetak dan media 
broadcast, maka media sosial menggunakan internet. Dengan demikian, media sosial sebagai sarana komunikasi memiliki peran membawa orang (penggunanya) untuk berpartisipasi secara aktif dengan memberi kontribusi dan feedback secara terbuka, baik untuk membagi informasi maupun memberi respon secara online dalam waktu yang cepat.

Berdasarkan data laporan We Are Social yang dikutip dari https://tekno.kompas.com, hingga Januari 2019, jumlah pengguna media sosial di Indonesia mencapai 150 juta pengguna atau 56 persen dari jumlah penduduk di Indonesia. Jumlah pengguna media sosial di Indonesia, meningkat 20 juta dari tahun lalu. Sebagian besar penggunanya adalah generasi milenial dengan rentang usia 18 hingga 34 tahun (Pertiwi, 2019).

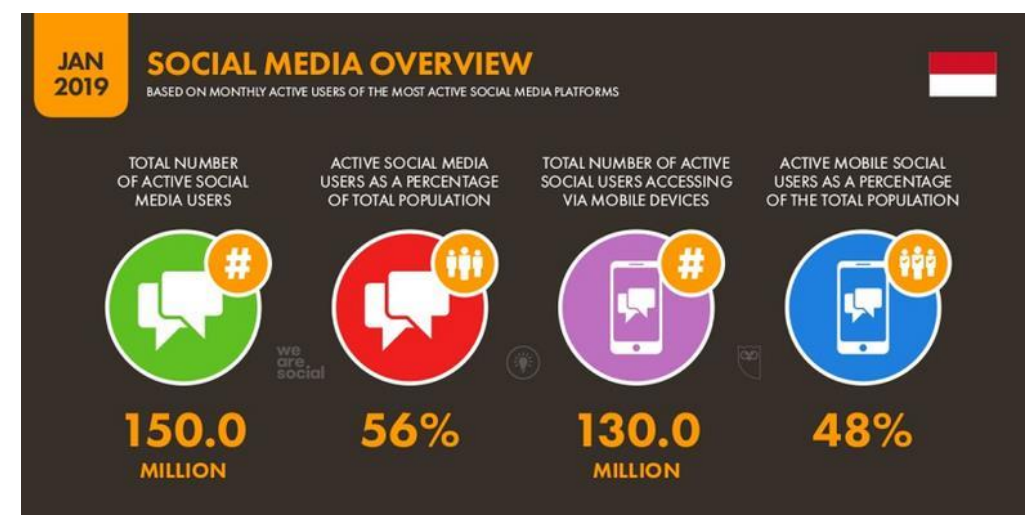

Gambar 1. Jumlah pengguna internet dan media sosial di Indonesia per Januari 2019

(Sumber: tekno.kompas.com)

Perangkat mobile seperti smartphone dan tablet masih menjadi perangkat favorit yang digunakan 130 juta pengguna media sosial aktif Indonesia, atau $48 \%$ dari total populasi Indonesia yang berjumlah sekira 268 juta orang.

Hampir seluruh pengguna media sosial di Indonesia menggunakan aplikasi pesan instan seperti WhatsApp atau Line. Penetrasi pengunaan aplikasi pesan instan sebesar 100 persen, sementara aplikasi media sosial kontribusi engagement-nya mencapai 92 persen. Sementara itu, orang-orang Indonesia banyak menghabiskan waktu 3 jam 26 menit untuk menggunakan media sosial dengan segala tujuan. Rata-rata, satu pengguna internet di Indonesia memiliki setidaknya 11 akun berbagai media sosial. Platform media sosial yang paling digandrungi oleh orang Indonesia, di antaranya YouTube, Facebook, WhatsApp, dan Line, sebesar 33\%.

Angka ini menjadi cerminan bahwa peluang pasar online terbuka sangat luas. Penggunanya seolah tidak pernah habis, malahan kian bertambah dari hari ke hari. Oleh karena itu, pemanfaatan media sosial sebagai media pemasaran pentig adanya dalam rangka peningkatan pesar oleh pengrajin olahan bambu di Kecamatan Selaawi, Kabupaten Garut.

Kegiatan PPM ini bertujuan untuk memberikan edukasi mengenai media sosial dan manfaatnya dalam memasarkan produk kerajinan bambu yang dihasilkan pengrajin di Kabupaten Garut. Target jangka panjang dari kegiatan ini, para pengrajin mau dan mampu mengoptimalkan penggunaan media sosial dalam memasarkan produk mereka sehingga memberikan impact berupa peningkatan income. Dengan peningkatan 
pendapatan, para pengrajin lebih bergairah lagi dalam memproduksi kerajinan olahan bambu.

\section{METODE}

Kegiatan PPM ini berlokasi di Kecamatan Selaawi, Kabupaten Garut, dengan kelompok sasarannya adalah para pengrajin/ pengusaha kerajinan bambu yang masih aktif menjalankan usahanya. Pemilihan lokasi di Selaawi, karena wilayah tersebut dikenal sebagai sentra kerajinan bambu, yang produk utamanya adalah sangkar burung, yang dihasilkan oleh warga Desa Mekarsari, Kecamatan Selaawi. Produk lainnya adalah anyaman serta home décor yang diproduksi oleh pengrajin di wilayah lainnya, yakni Desa Selaawi dan Mekarsari. Hasil kerajinan bambu lainnya berupa peralatan rumah tangga seperti boboko, hihid, aseupan, tudung saji, dan sebagainya. Selain sangkar burung yang sudah memiliki pasar yang jelas, kerajinan anyaman bambu dipasarkan dalam area terbatas, hanya di wilayah Selaawi dan sekitarnya, serta Bandung yang dilakukan secara konvensional.

Keterampilan menggunakan media sosial yang diperoleh para pengrajin melalui kegiatan PPM ini, diharapkan dapat lebih meluaskan distribusi dan promosi kerajinan bambu Selaawi, Garut sehingga dapat membantu pengrajin dalam menambah pendapatan. Selain itu, komunikasi di antara pengrajin pun dapat terjalin lebih erat melalui jaringan media sosial percakapan, seperti WhatsApp dan Facebook.

Tema kegiatan Program PPM ini berkaitan dengan pendidikan dan ekonomi. Dalam kaitannya dengan pendidikan, PPM ini memberikan pelatihan mengenai media sosial kepada pengrajin bambu yang belum menggunakan media sosial serta pengrajin yang belum optimal dalam menggunakan media sosial sebagai saluran pemasaran dan promosi produk kerajinan bambu yang dihasilkan. Pelatihan diberikan untuk meningkatkan pengetahuan pengrajin mengenai media sosial dan pemanfaatannya untuk menunjang pemasaran produk kerajinan bambu yang selama ini dilakukan secara konvensional, dengan menjual langsung maupun mendistribusikannya kepada agen-agen penjualan produk kerajinan bambu. Kaitannya dengan ekonomi, peningkatan keterampilan menggunakan media sosial sebagai saluran promosi dan pemasaran kerajinan bambu diharapkan dapat mendatangkan konsumen yang membeli produk kerajinan bambu sehingga menambah pendapatan pengrajin.

Pelatihan ini dapat dikategorikan sebagai pendidikan masyarakat, yakni penyuluhan yang bertujuan untuk meningkatkan pemahaman warga. Dalam hal ini, pelatihan dimaksudkan untuk meningkatkan pemahaman warga tentang manfaat media sosial dalam pemasaran. Kegiatan PPM ini menghadirkan pemateri yang menyajikan materi yang sesuai dengan tema PPM, yakni tentang pemanfaatan media sosial dalam memasarkan produk kerajinan bambu Selaawi, Kabupaten Garut. Mereka adalah Ridwan Effendi, Camat Selaawi, Harry Mawardi (owner Amygdala Bamboo) dan Utang Mamad (Koordinator pengrajin bambu di Selaawi).

\section{Tahap Persiapan}

Sesuai dengan penjelasan yang telah disampaikan, kegiatan PPM ini dilaksanakan secara daring melalui aplikasi Zoom Cloud Meetings dan melalui tiga tahapan utama, 
yakni tahap persiapan, tahap pelaksanaan dan tahap evaluasi. Pada tahap persiapan tim PPM dibantu mahasiswa KKN, menyiapkan sarana dan prasarana yang diperlukan demi kelancaran pelaksanaan PPM tersebut, diantaranya flyer acara, spanduk yang ditampilkan sebagai background peserta kegiatan PPM melalui Zoom Cloud Meetings, menyiapkan akun Zoom yang akan digunakan dalam PPM virtual, undangan, rundown acara, plakat bagi pemateri, serta sertifikat bagi peserta kegiatan, pembawa acara dan host. Selain itu, untuk menunjang kelancaran berlangsungnya PPM secara daring, tim PPM mengakomodasi kuota internet kepada para pengrajin peserta pelatihan dan narasumber. Tim dosen pun mengurus perijinan kegiatan ke kantor Kecamatan Selaawi dan pendataan fasilitas untuk pelaksanaan kegiatan,

Berikut beberapa perlengkapan yang dipersiapkan sebelum dilangsungkannya PPM daring bagi para pengrajin bambu di Kecamatan Selaawi, Kabupaten Garut:

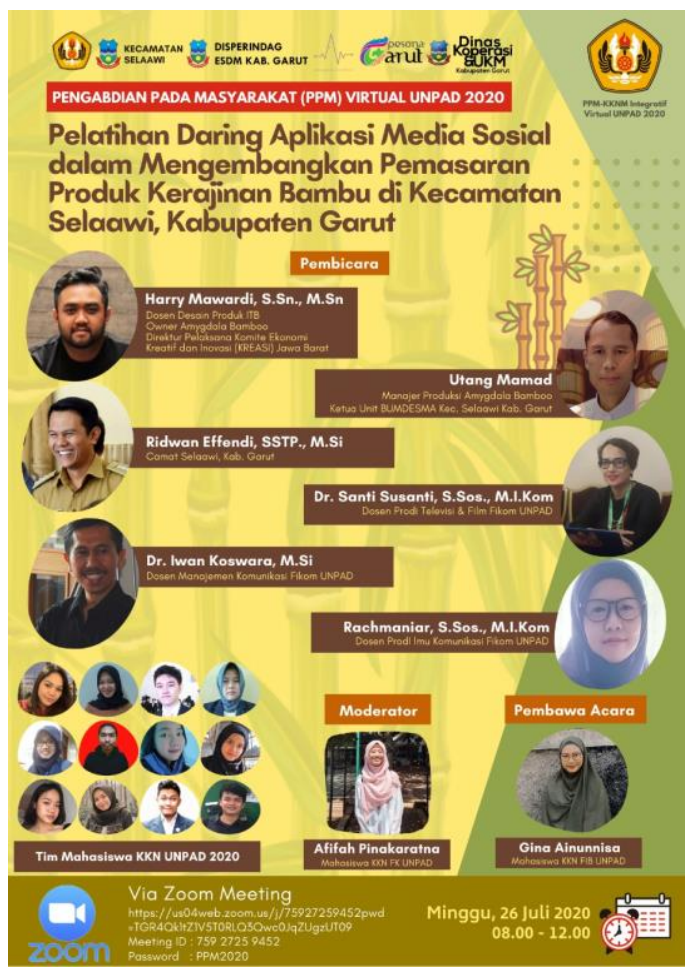

Gambar 2. Flyer PPM Daring 2020

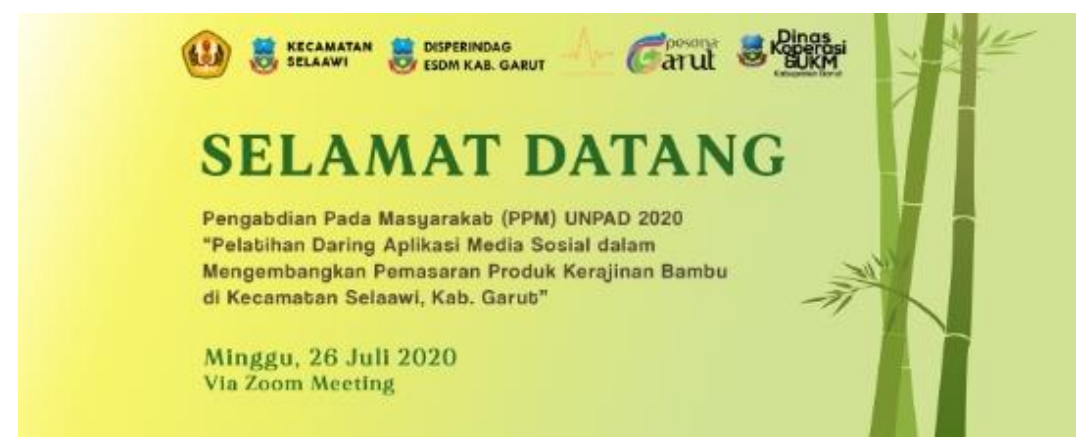

Gambar 3. Spanduk PPM Daring 


\section{Pelaksanaan PPM}

Pengabdian pada masyarakat ini dilaksanakan pada Sabtu, 26 Juli 2020, melalui aplikasi Zoom Cloud Meetings. Mulai dari jam 08.00 pagi sampai jam 1 siang. Peserta kegiatan ini adalah pengrajin bambu di Kabupaten Garut yang diundang untuk menghadiri acara.

Kegiatan dilaksanakan dengan metode ceramah dengan tujuan memberikan pemahaman pengetahuan, pemahaman aplikasi dan pemahaman analisis, sintesis serta evaluasi (Syah, 1995). Pada setiap akhir sesi ceramah, peserta diberi kesempatan untuk bertanya kepada pemateri mengenai pemasaran produk kerajinan bambu melalui jalur online. Materi yang diberikan adalah sebagai berikut:

Tabel 1. Pemateri dan Judul Presentasi PPM Daring

\begin{tabular}{clll}
\hline No & \multicolumn{1}{c}{ Nama } & \multicolumn{1}{c}{ Jabatan } & \multicolumn{1}{c}{ Judul Presentasi } \\
\hline 1. & $\begin{array}{l}\text { Ridwan Effendi, SSTP., } \\
\text { M.Si. }\end{array}$ & Camat Selaawi & $\begin{array}{l}\text { Industri Bambu Kreatif } \\
\text { Selaawi }\end{array}$ \\
\hline & $\begin{array}{l}\text { Harry Mawardi, S.Sn., } \\
\text { M.Sn. }\end{array}$ & $\begin{array}{l}\text { Owner Amygdala } \\
\text { Bamboo }\end{array}$ & $\begin{array}{l}\text { Penyajian Produk sebagai } \\
\text { Stategi Promosi (Aplikasi } \\
\text { pada Online) }\end{array}$ \\
\hline & & $\begin{array}{l}\text { Koordinator } \\
\text { Pengrajin Bambu } \\
\text { S. }\end{array}$ & $\begin{array}{l}\text { Berbagi pengalaman } \\
\text { menekuni kerajinan bambu } \\
\text { di Selaawi }\end{array}$ \\
\hline
\end{tabular}

Sumber: Data PPM 2020

\section{HASIL DAN PEMBAHASAN}

Pada tahap ini, PPM dilaksanakan pada 26 Juli 2020, dengan menghadirkan peserta para pengrajin bambu di Kecamatan Selaawi, serta narasumber yang kompeten dalam membahas kerajinan bambu di Selaawi. Materi pertama disampaikan oleh Harry Mawardi, S.Sn., M.Sn., pemilik Amygdala Bamboo, dengan judul Penyajian Produk sebagai Strategi Promosi. Dalam presentasinya, dosen seni rupa ITB ini menekankan pentingnya penyajian foto saat mempromosikan produk yang dihasilkan pengrajin. Menurut Harry, dalam promosi, yang paling penting adalah kualitas produknya. Selain itu penyajian foto, yang meliputi background, pengambilan gambar dan lainnya.

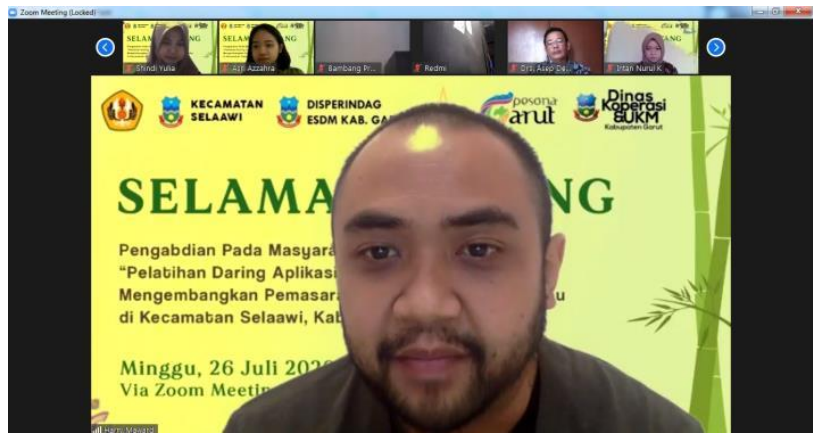

Gambar 4. Harry Mawardi, Pemilik Amygdala Bamboo, memberikan materi pelatihan PPM 
Harry menjelaskan, foto produk sama pentingnya dengan produk. Kesalahan yang umum terjadi dalam mengambil foto adalah fotonya buram, tampak jauh, tidak memerhatikan latar, tidak peduli cahaya sekitarnya, tidak fokus pada produk. Kualitas foto yang baik menurut Harry bisa memengaruhi psikologis seseorang dalam menentukan keputusan membeli produk. Pengemasan foto yang bagus juga dapat menarik calon konsumen untuk membeli produk yang ditawarkan. Media yang dapat dimanfaatkan untuk memasarkan produk secara online antara lain Facebook, Instagram, dan marketplace seperti Bukalapak, Tokopedia, Blibli, dan lainnya.

Pada bagian akhir presentasinya, Harry memberikan tips foto pemasaran produk, yakni:

1. Tunjukan detail keuggulan

1) Tampilkan bagaimana cara menggunakan produk

2) Tunjukan bagaimana produk tersebut paling cocok ditempatkan

3) Gunakan objek yang memikat

4) Untuk foto menarik, tidak harus mahal, bisa juga menggunakan kamera handphone

Materi kedua disampaikan oleh Camat Selaawi, Bapak Ridwan Effendi, SSTP., M.Si., dengan judul presentasi "Pembangunan Kawasan Berbasis Potensi Unggulan". Dalam pemaparannya, Pak Camat menggambarkan potensi Selaawi sebagai sentra kerajinan bambu yang sudah dikenal luas hingga ke luar negeri. Sebagai sentra kerajinan bambu, kawasan Selaawi didukung ketersediaan 600 hektar lahan yang ditanami beragam jenis bambu yang tersebar di tujuh desa.

Beragam potensi yang terkait dengan bambu dapat dikembangkan di Selaawi. Persoalannya, ketersediaan sumber daya manusia yang masih kurang. Oleh karena itu, menurut Ridwan, perlu adanya peningkatan jumlah tenaga terampil dalam bidang pengolahan bambu di Selaawi untuk mendukung pengembangan usaha bambu di kawasan Garut Utara tersebut. Untuk itu dibutuhkan kerjasama yang sinergis antara berbagai berbagi pihak untuk mendukung pengembangannya.

Salah satu yang perlu diberikan bagi para pengrajin di Selaawi adalah keterampilan manajerial. Untuk mendukung promosi Selaawi sebagai sentra kerajinan bambu, maka Pemerintah Garut membangun Bamboo Creative Center sebagai bentuk nyata bantuan pemerintah dalam memajukan potensi kerajinan bambu di Selaawi.

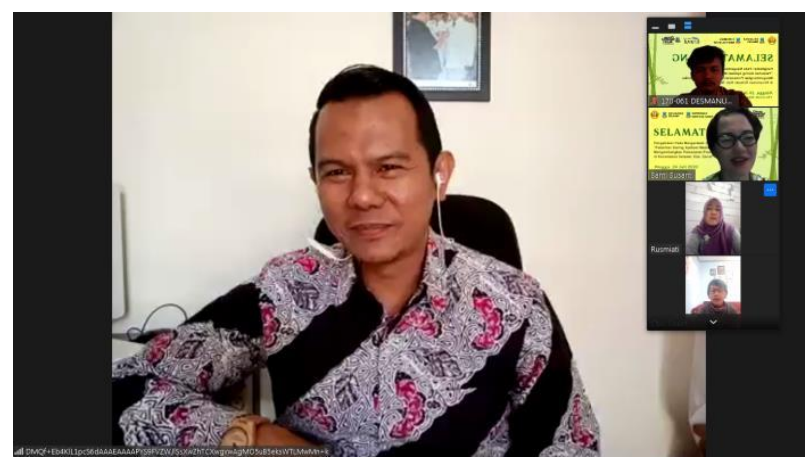

Gambar 5. Ridwan Effendi, SST, M.Si., Camat Selaawi, saat memberikan materi kepada peserta PPM

Materi berikutnya disampaikan oleh Utang Mamad, Kepala Unit Badan Usaha Milik Desa Bersama (Bumdesma) Kecamatan Selaawi, sekaligus pengrajin yang bekerjasama 
dengan Harry Mawardi dalam memproduksi kerajinan bambu yang dirancang oleh Harry. Dalam sesi ini, Pak Utang lebih banyak bercerita pengalamannya menekuni kerajinan bambu. Dalam posisinya sebagai Kepala Unit Bumdesma, Pak Utang mengakui adanya permasalahan dalam "tubuh" pengrajin bambu Selaawi, yakni pemasaran dalam media sosial. Seorang pengrajin dan wirausaha harus selalu konsisten dalam jenis usahanya jangan mudah terbawa arus supaya kita bisa mudah dikenal oleh banyak orang. Di Selaawi perlu adanya peningkatan komunikasi antara pengrajin, pemerintah, dan instansi terkait supaya kerajinan di Selaawi dapat dikenal dan lebih maju lagi. Saatnya untuk berbagi peran melalui jejaring dengan lainnya.

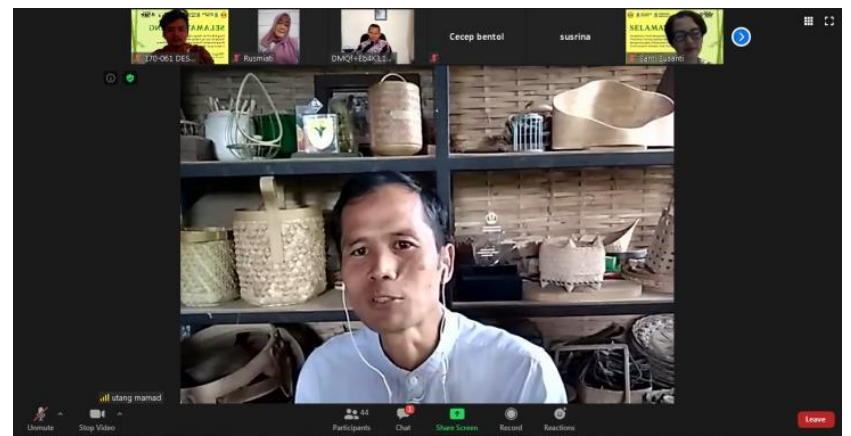

Gambar 6. Utang Mamad, Koordinator Pengrajin di Selaawi, saat berbagi pengalaman menjadi pengrajin bambu Selaawi

Menurut Pak Utang, untuk mencapai keberhasilan, pengrajin harus terus belajar dan memperbaiki diri. Kesukseskan akan menyusul. Diskusi berlangsung dengan hangat. Setelah para narasumber menyampaikan materinya, peserta diberikan kesempatan untuk bertanya. Pada saat diskusi inilah suasana jadi hidup, karena para pengrajin peserta PPM sangat antusias untuk menanggapi keterangan yang disampaikan oleh narasumber. Setiap narasumber mendapat pertanyaan dari peserta yang ingin mengetahui tentang foto produk, maupun penggunaan media sosial sebagai media untuk pemasaran.

\section{SIMPULAN}

Media sosial memiliki manfaat besar bagi individu maupun kelompok usaha yang ingin produknya mencapai pangsa pasar yang lebih luas. Salah satunya pengrajin bambu di Selaawi, Kabupatan Garut, Jawa Brat. Banyak media sosial yang bisa digunakan, tinggal dipilih sesuai dengan kemampuan individu untuk mengelolanya. Meski terlihat mudah, tetapi, ada beberapa ketentuan yang harus dipenuhi oleh para pengrajin agar produknya dapat diminati oleh calon konsumen. Sejumlah narasumber yang terlibat dalam Pelatihan Daring Pemanfaatan Media Sosial dalam Pemasaran Produk Kerajinan Bambu di Selaawi, Garut, Jawa Barat, membagikan ceritanya seputar pemasaran yang berkaitan dengan kerajinan bambu di Selaawi. Antusiasme para peserta dalam bertanya maupun mengikuti kegiatan hingga akhir menunjukkan rasa ingin tahu yang cukup besar dari para pengrajin untuk memperoleh pengetahuan mengenai pemanfaatan media sosial sebagai media pemasaran produk bambu. 
Adanya kegiatan PPM ini merupakan salah satu bagian dari pengabdian perguruan tinggi kepada masyarakat, agar memberikan manfaat yang sebesar-besarnya. Tim PPM Fikom Unpad berharap, kegiatan PPM yang dilaksanakan secara daring melalui aplikasi Zoom Meetings ini menjadi awal bagi pengrajin bambu, khususnya pengrajin anyaman bambu di Selaawi Garut, untuk dapat memanfaatkan media sosial sebagai saluran pemasaran produk kerajinan bambu yang mereka hasilkan.

\section{Ucapan Terima Kasih}

Pengabdian Pada Masyarakat ini merupakan bagian dari Program Hibah Internal Unpad, yang pendanaannya bersumber dari universitas. Oleh karena itu, kami, tim PPM Fikom Unpad, mengucapkan terima kasih kepada Universitas Padjadjaran atas kepercayaan dan pendanaan yang diberikan untuk mendukung pelaksanaan PPM ini.

\section{REFERENSI}

Ardianto, E. (2011). Handbook of public relations. Bandung: Simbiosa Rekatama Media.

bisnisbandung.com. (2017). Jabar andalkan industri kreatif bambu. Diakses dari http://bisnisbandung.com/jabar-andalkan-industri-kreatif-bambu/

Disperindagpas Kabupaten Garut, \& Buana, D. R. C. (2015). Laporan akhir kajian keterkaitan produksi industri hulu dan hilir komoditas bambu. Garut: Disperindagpas Kabupaten Garut.

Kaplan, A. M., \& Haenlein, M. (2010). Users of the world, unite! The challenges and opportunities of Social Media. Business Horizons, 53(1), 59-68.

Kasmudjo. (2010). Teknologi hasil hutan. Yogyakarta: Cakrawala Media.

Mawardi, H. (2020). Hasil wawancara pribadi. 9 Januari 2020. Bandung.

Pertiwi, W. K. (2019). Separuh penduduk Indonesia sudah 'melek' "media sosial". Retrieved September 19, 2020, from https://tekno.kompas.com/read/2019/02/04/19140037/separuhpenduduk-indonesia-sudah-melek-media-sosial

Syah, M. (1995). Psikologi pendidikan, suatu pendekatan baru. Bandung: Remaja Rosdakarya.

\section{Copyright and License}

This is an open access article distributed under the terms of the Creative Commons Attribution 4.0 International License, which permits unrestricted use, distribution, and reproduction in any medium, provided the original work is properly cited.

(C) 2020 Santi Susanti, Rachmaniar, Iwan Koswara. 